Article

\title{
Immobilization/Stabilization of Ficin Extract on Glutaraldehyde-Activated Agarose Beads. Variables That Control the Final Stability and Activity in Protein Hydrolyses
}

\author{
El-Hocine Siar ${ }^{1,2,+}$, Sara Arana-Peña ${ }^{1,+}$, Oveimar Barbosa ${ }^{3}$, Mohammed Nasreddine Zidoune ${ }^{2}$ \\ and Roberto Fernandez-Lafuente ${ }^{1, * \text { (D) }}$ \\ 1 Departamento de Biocatálisis, Instituto de Catálisis-CSIC, Campus UAM-CSIC, 28049 Madrid, Spain; \\ hocines1@hotmail.fr (E.-H.S.); sara_arana@hotmail.com (S.A.-P.) \\ 2 Equipe TEPA, Laboratoire LNTA, INATAA, Université des Frères Mentouri Constantine 1, \\ 25000 Constantine, Algeria; zidounem@yahoo.fr \\ 3 Departamento de Química, Facultad de Ciencias, Universidad del Tolima, 730006299 Ibagué, Colombia; \\ oveimar@gmail.com \\ * Correspondence: rfl@icp.csic.es; Tel.: +34-915-854-941 \\ + Both authors have evenly contributed to this paper.
}

Received: 12 March 2018; Accepted: 2 April 2018; Published: 6 April 2018

\begin{abstract}
Ficin extract has been immobilized on different $4 \%$ aminated-agarose beads. Using just ion exchange, immobilization yield was poor and expressed activity did not surpass $10 \%$ of the offered enzyme, with no significant effects on enzyme stability. The treatment with glutaraldehyde of this ionically exchanged enzyme produced an almost full enzyme inactivation. Using aminated supports activated with glutaraldehyde, immobilization was optimal at pH 7 (at pH 5 immobilization yield was $80 \%$, while at $\mathrm{pH} 9$, the immobilized enzyme became inactivated). At $\mathrm{pH} 7$, full immobilization was accomplished maintaining $40 \%$ activity versus a small synthetic substrate and $30 \%$ versus casein. Ficin stabilization upon immobilization could be observed but it depended on the inactivation $\mathrm{pH}$ and the substrate employed, suggesting the complexity of the mechanism of inactivation of the immobilized enzyme. The maximum enzyme loading on the support was determined to be around $70 \mathrm{mg} / \mathrm{g}$. The loading has no significant effect on the enzyme stability or enzyme activity using the synthetic substrate but it had a significant effect on the activity using casein; the biocatalysts activity greatly decreased using more than $30 \mathrm{mg} / \mathrm{g}$, suggesting that the near presence of other immobilized enzyme molecules may generate some steric hindrances for the casein hydrolysis.
\end{abstract}

Keywords: immobilization using glutaraldehyde; versatility of glutaraldehyde; steric problems in enzyme activity; effect of loading on enzyme activity

\section{Introduction}

Proteases are among the first enzymes used by humans in biotechnological food processing [1,2]. Nowadays, proteases are used in many different areas, for example in the production of active peptides from inexpensive proteins, to improve the organoleptic or functional properties of foods [3], although perhaps its main use is as detergent components [4-7]. In some instances, a chemical alternative exists [8] but proteases have clear advantages, as the process will be more specific, avoiding the production of by-products or destruction of some amino acids [9]. Among the most used proteases of vegetal origin, the latex of the fig tree (based in ficin) should be mentioned. It has been employed in the brewing [9], pharmaceutical [10] and in cheese making [11,12] industries. It has also been used 
for bioactive peptides production $[13,14]$ and meat tenderization $[15,16]$. Ficin is considered to give a more reproducible hydrolysis map and it has been employed in the generation of antibodies via specific hydrolysis of some peptide bonds, [17-19]. Four isoforms of ficin have been described (A, B, C and D) and crystallized, resolving their structure [20,21]. Ficin isoforms are glycoproteins and present a high sequence similarity with bromelaine [22].

The immobilization of an enzyme may facilitate enzyme reuse and that way, the economic feasibility of the process [23-26]. Moreover, immobilization may be used to improve other enzyme limitations, like stability, activity, resistance to chemicals or inhibitors, even purity [27-29]. In the case of proteases to be used in protein hydrolysis, there are specific problems that must be considered: the enzyme must have the active centre properly oriented; otherwise the enzyme will be inactive [1]. Only when the active centre is fully oriented to the medium, the protease will be active under any loading; if the active centre is not "perfectly" oriented, the fully loaded biocatalyst may become fully inactive versus proteins larger than the immobilized protease molecule [30]. This steric problem will be coupled to the standard diffusional limitations, even if the active centre is fully intact [31] or a non-porous nanoparticle is utilized [32]. However, due to the multiple uses of proteases, this should not discard the biocatalysts for other uses, for example synthesis of peptide bonds [33-35]. Ficin has been immobilized in just some few examples [36-40].

In this sense, immobilization of ficin using the glutaraldehyde chemistry may benefit from the versatility of the system [41]. In most cases, glutaraldehyde is used to activate supports containing primary amino groups. This way, the glutaraldehyde activated support becomes a heterofunctional one, with the range of opportunities that this may open. Thus, the enzyme may be directly immobilized at high ionic strength via a covalent reaction using glutaraldehyde pre-activated supports, or may be first ionically exchanged [42-44]. That way, using a support with the amino groups modified with glutaraldehyde, the enzymes may be ionically exchanged at low ionic strength and later a covalent reaction between the immobilized enzyme molecules and the nearby glutaraldehyde groups may take place, or using high ionic strength, the ionic adsorption will be prevented, forcing the covalent attachment as first event of the immobilization. Using just the aminated support, the ionic exchange will permit to immobilize the enzyme, later the treatment with glutaraldehyde may permit to establish support-enzyme bonds. In this case, together with enzyme-support reactions, modification of the overall enzyme surface occurs (one point modification, inter or intramolecular crosslinking) and this may have positive, negative or neutral effects on enzyme performance [41]. The possibilities of altering the enzyme orientation regarding the support surface and that way, of increasing the possibility of yielding immobilized enzyme preparations with different properties, may be enlarged considering that the conditions where the ion exchange is performed, for example the $\mathrm{pH}$ value, may also alter the orientation of the enzyme regarding the support surface [45-47].

Previously, our research group has immobilized ficin extract in glyoxyl activated support, focused only on the stability of lowly loaded enzyme immobilized preparations [40]. In this new research effort, ficin extract has been immobilized on amino and amino glutaraldehyde agarose beads, trying to explore the versatility of glutaraldehyde to get a biocatalyst with high activity and stability. In this new paper, the effect of the protein loading on enzyme activity versus small synthetic substrate (benzoyl-arginine- $p$-nitroanilide (BANA)) and large casein was analysed [1,30,31], as well as the likely effects on enzyme stability, as the loading may affect the distance between different immobilized enzyme molecules and that, in turn, enzyme stability $[48,49]$.

\section{Results and Discussion}

\subsection{Immobilization of Ficin Extract in MANAE-Agarose}

Figure 1 shows the immobilization courses at $\mathrm{pH} 5,7$ and 9 of ficin on aminated supports. Immobilization was very slow at all studied $\mathrm{pH}$ values, with a significant decrease in enzyme activity, although the free enzyme maintained full activity. Yields were higher at $\mathrm{pH} 9$ than at $\mathrm{pH} 5$ or 7 , although 
expressed activity (the observed activity of the immobilized enzyme compared to the expected one from the immobilization yields data) was always very low (just near to $10 \%$ ). To check of the yield was determined by the full loading of the support, the supernatant was used in a new immobilization cycle (at pH 7) and a similar immobilization yield was observed (results not shown). This suggest that the yield was not caused by the overloading of the support or by the presence of some enzyme isoforms that cannot be immobilized on the support, suggesting that was due to some kind of adsorption equilibrium. The activity was determined with casein and the small synthetic substrate (BANA), with scarce differences. These facts suggested two contradictory ideas: the ion exchange was so mild that it was unable to fully adsorb the enzyme but the immobilization produces very negative effects on enzyme structure that yielded a decrease versus small and large substrates. Figures $2-5$ show the distribution of anionic and main cationic residues on the 4 isoforms of ficin component. In most cases, there is not an area clearly richer in anionic residues than in cationic ones; this may explain why immobilization via ionic exchange is so slow and ineffective. However, in all sides of the proteins there are some Lys groups that could give at least one covalent attachment after ion exchange if treated with glutaraldehyde.
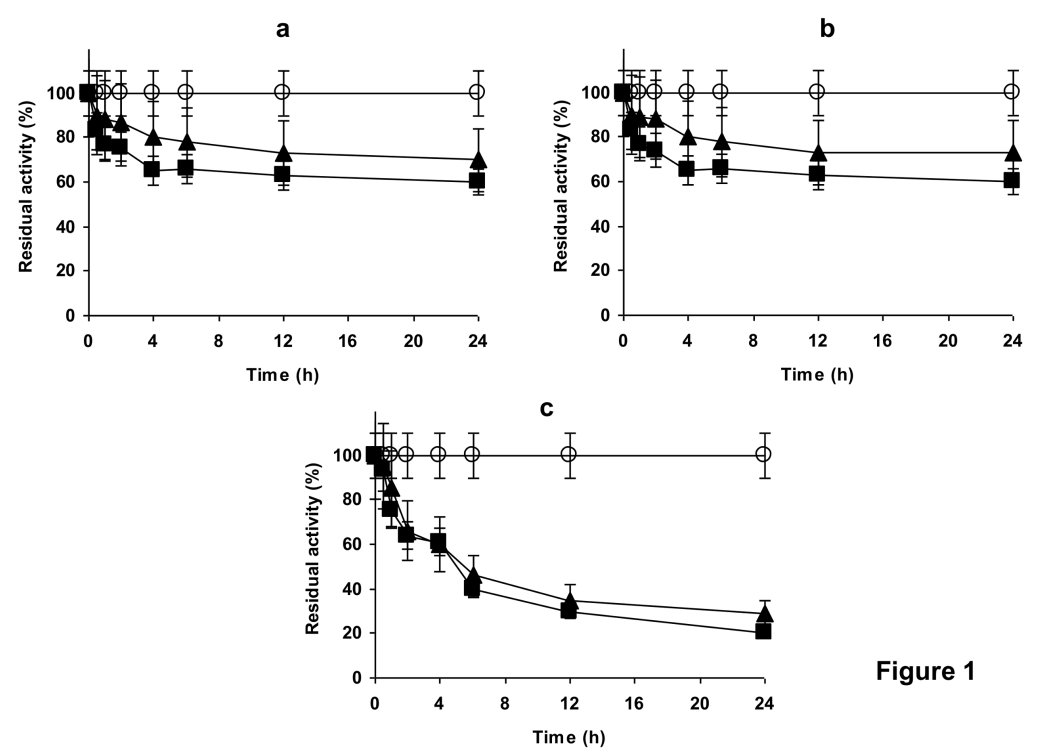

Figure 1

Figure 1. Immobilization of ficin extract on MANAE-agarose beads at pH 5 (a), 7 (b) or 9 (c). Immobilization was performed as described in methods. Activity was followed using BANA as substrate. Circles: reference; Triangles: suspension, Squares: supernatant.

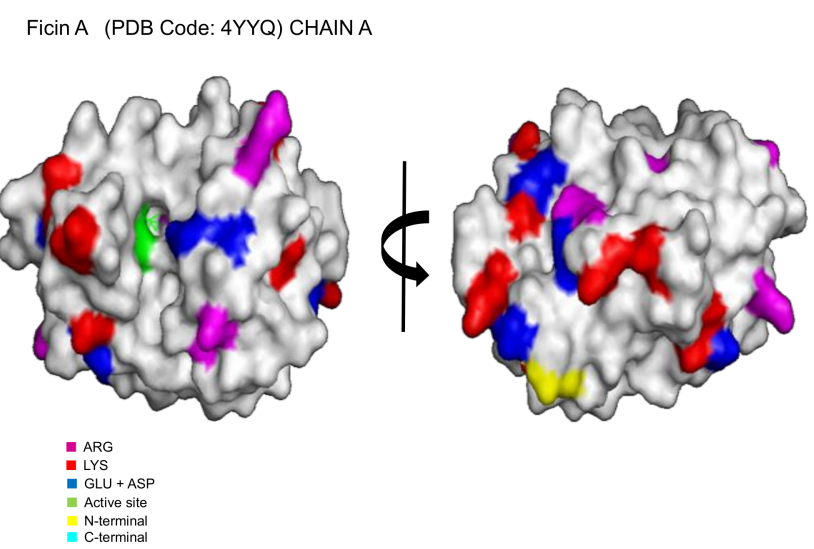

Figure 2. 3D surface structure model of Ficin A obtained from the Protein Data Bank (PDB) and displayed using PyMol versus 0.99. Arg, $\mathrm{Lys}, \mathrm{Glu}+\mathrm{Asp},-\mathrm{NH}_{2}$ terminal and $-\mathrm{COOH}$ terminal residues are indicated. 


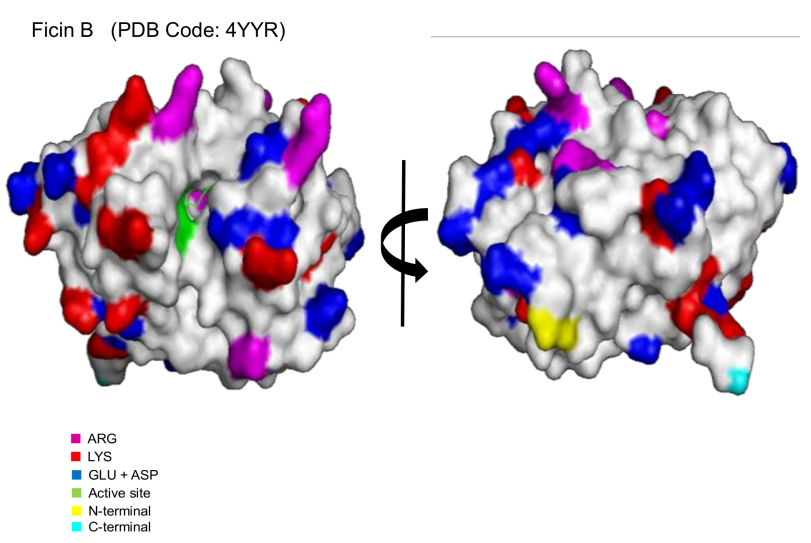

Figure 3. 3D surface structure model of Ficin B obtained from the PDB and displayed using PyMol versus 0.99. Arg, Lys, Glu+Asp, $-\mathrm{NH}_{2}$ terminal and $-\mathrm{COOH}$ terminal residues are indicated.

Ficin C (PDB Code: 4YYV)

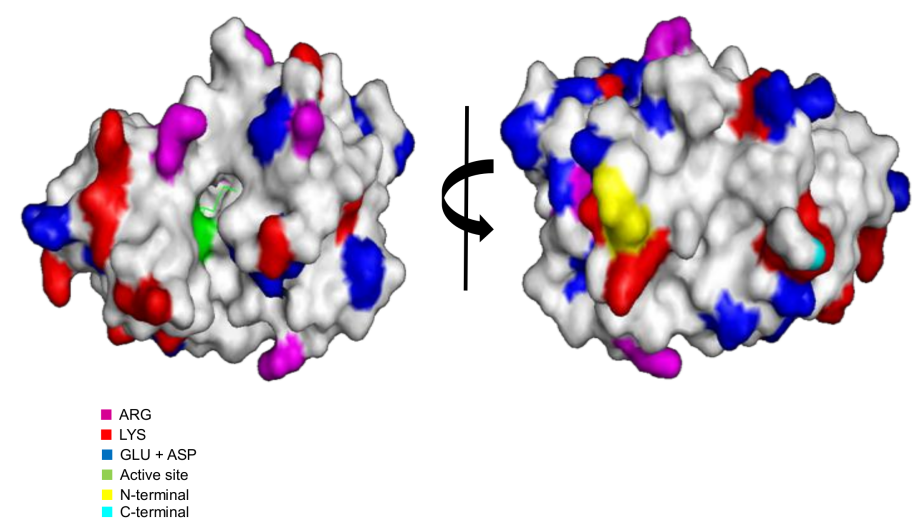

Figure 4. 3D surface structure model of Ficin $\mathrm{C}$ obtained from the PDB and displayed using PyMol versus 0.99. Arg, Lys, Glu+Asp, $-\mathrm{NH}_{2}$ terminal and $-\mathrm{COOH}$ terminal residues are indicated.

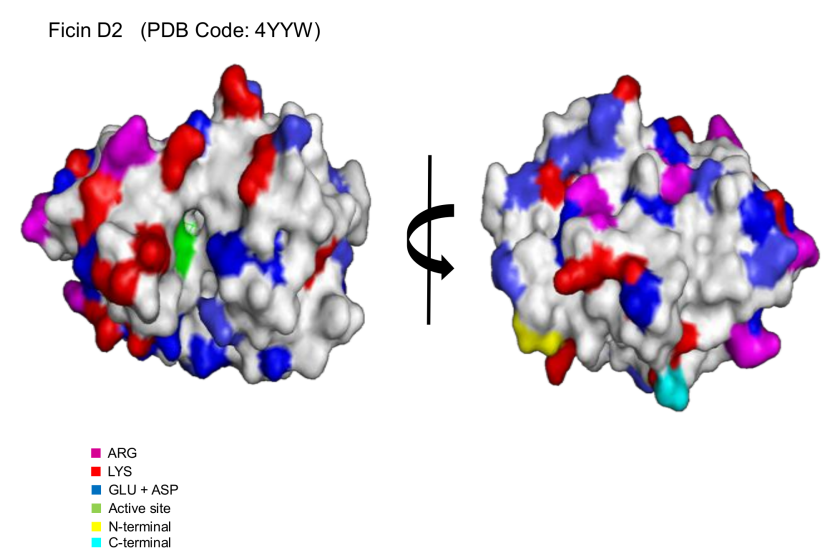

Figure 5. 3D surface structure model of Ficin $\mathrm{D}_{2}$ obtained from the PDB and displayed using PyMol versus 0.99 . Arg, Lys, Glu+Asp, $-\mathrm{NH}_{2}$ terminal and $-\mathrm{COOH}$ terminal residues are indicated.

Figure 6 shows the inactivation of the ionically exchanged proteins at $\mathrm{pH} 7$ when inactivated at $\mathrm{pH} 5, \mathrm{pH} 7$ and $\mathrm{pH}$ 9. A slight stabilization may be found at $\mathrm{pH} 5$ and 9, while a slight destabilization may be found at $\mathrm{pH}$ 7. These differences may be based in the way the free enzyme is inactivated. The free enzyme may suffer enzyme autolysis, that way reducing the enzyme stability/activity. 
Moreover, the free enzyme may experience protein aggregation (mainly near to the isoelectric point). These two inactivations are not possible using an immobilized enzyme form [30]. In fact, under conditions where aggregation is quite unlikely, stability of the enzyme decreased after immobilization. This may be caused by undesired enzyme-support interactions where inactivation that can stabilize incorrect enzyme structures $[29,50,51]$.

These results were not very positive and anion exchange was discarded as a likely one to immobilize ficin.
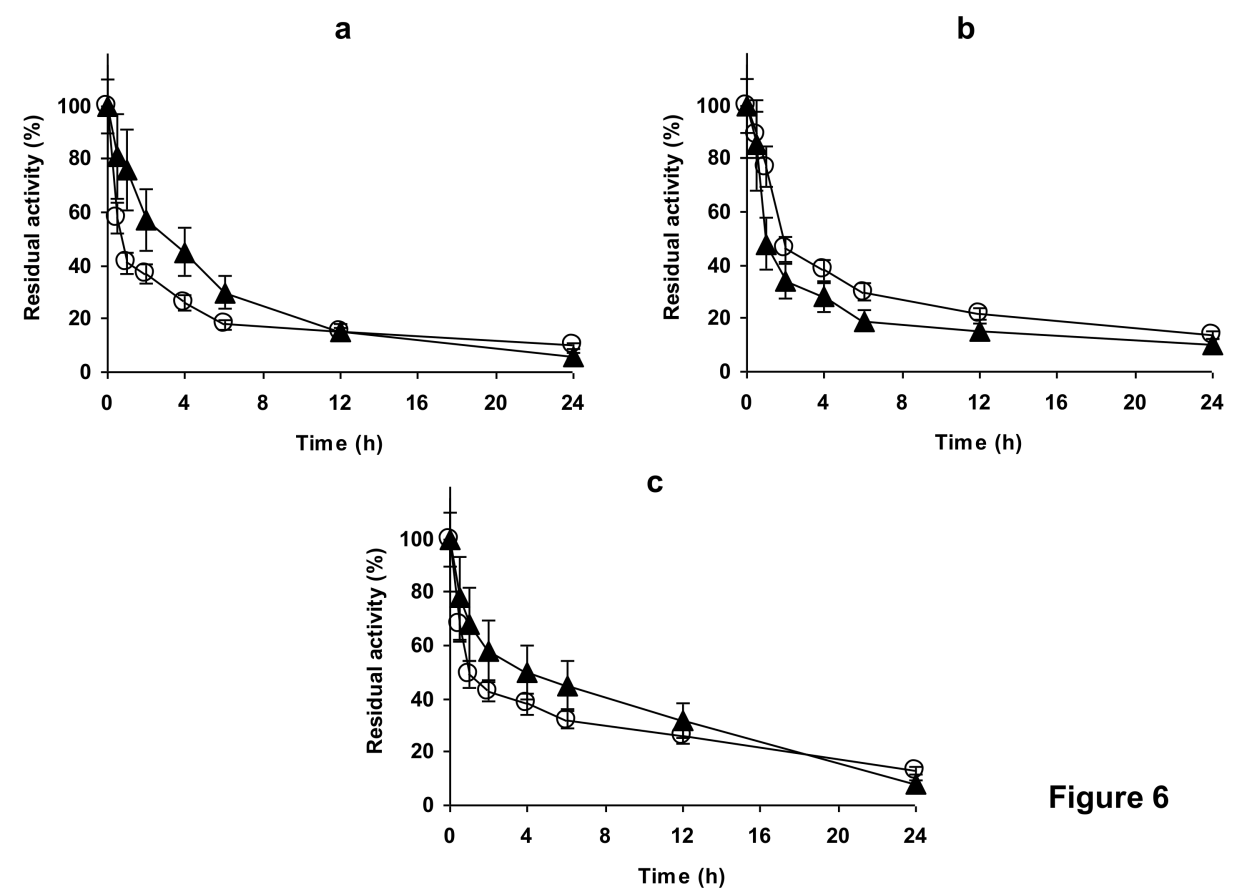

Figure 6

Figure 6. Inactivation courses of the ionically exchanged ficin extract on MANAE-agarose beads at $\mathrm{pH}$ 7. The inactivation studies were performed as indicated in Methods section at $\mathrm{pH} 5,(\mathbf{a}), 7$ (b) or 9 (c) at $55{ }^{\circ} \mathrm{C}$, using BANA as substrate. Circles: Free enzyme. Triangles: immobilized enzyme.

\subsection{Modification of the Ionically Exchanged Enzyme with Glutaraldehyde}

In a trial to improve the stability of the ionically exchanged enzyme, the immobilized enzyme was treated with glutaraldehyde, even although the expressed activity of this preparation was already quite low. When the ionically exchanged enzyme was modified with glutaraldehyde, most of the remaining activity was lost, making unsuitable this strategy to improve the enzyme stability.

To check if the problem was a consequence of a too intense support-enzyme reaction or the chemical modification of the enzymes with glutaraldehyde, the enzyme immobilized on glyoxyl agarose was modified with glutaraldehyde under the conditions used to modify the adsorbed enzyme. Figure 7 shows how the modification of the glyoxyl-ficin biocatalyst with glutaraldehyde produces some enzyme inactivation, suggesting that the direct modification of the enzyme with this chemical reagent could be partially responsible of the enzyme inactivation. As this preparation was more stable than the free enzyme [40], it may be expected that the enzyme may be also more stable versus chemical modification [52]. However, using the aminated support the residual activity was under $10 \%$ after $1 \mathrm{~h}$ (Figure 7), suggesting that an inactivation caused by the activated support and enzyme reaction cannot be discarded. 


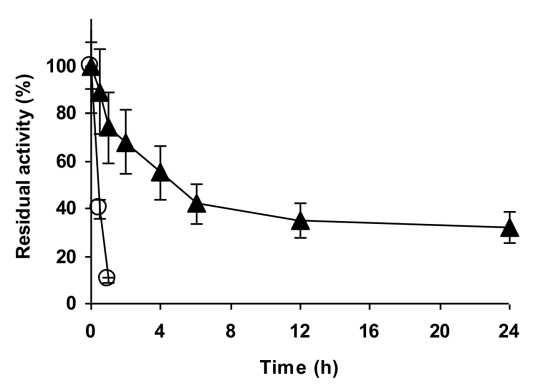

Figure 7. Modification of glyoxyl (triangles) or MANAE agarose (circles) immobilized ficin extract when incubated in $1 \%$ glutaraldehyde at $\mathrm{pH} 7$. Experiments were performed as described in Methods using BANA as substrate.

\subsection{Immobilization of the Enzyme in Glutaraldehyde Pre-Activated MANAE Agarose Beads}

Figure 8 shows the immobilization course at pH 5, 7 and 9 of ficin extract on glutaraldehyde pre-activated agarose beads. At pH 5 immobilization yield was $80 \%$ after $24 \mathrm{~h}$ and only $20 \%$ of the initial activity was present in the immobilized biocatalyst. Thus, this preparation was discarded. At $\mathrm{pH} 9$ the enzyme was almost fully immobilized after $6 \mathrm{~h}$ but the enzyme was almost fully inactivated $(16 \%$ after $24 \mathrm{~h})$. That way, this preparation was also discarded. However, when the enzyme was immobilized at $\mathrm{pH} \mathrm{7,} \mathrm{full} \mathrm{immobilization} \mathrm{was} \mathrm{obtained} \mathrm{after} 4 \mathrm{~h}$ and the expressed activity was around $40 \%$ versus BANA. When the activity was followed versus casein, initially both lines were almost identical, suggesting that immobilized ficin molecules had no reduced accessibility to the casein substrate (that is, the active centre is not oriented towards the support surface). When $24 \mathrm{~h}$ of enzyme-support interaction were permitted, the activity versus casein was a $25 \%$ lower than versus BANA (about $40 \%$ versus about 30\%), suggesting that the changes of the enzyme structure during support-enzyme interactions may affect more to the activity versus casein that versus BANA.
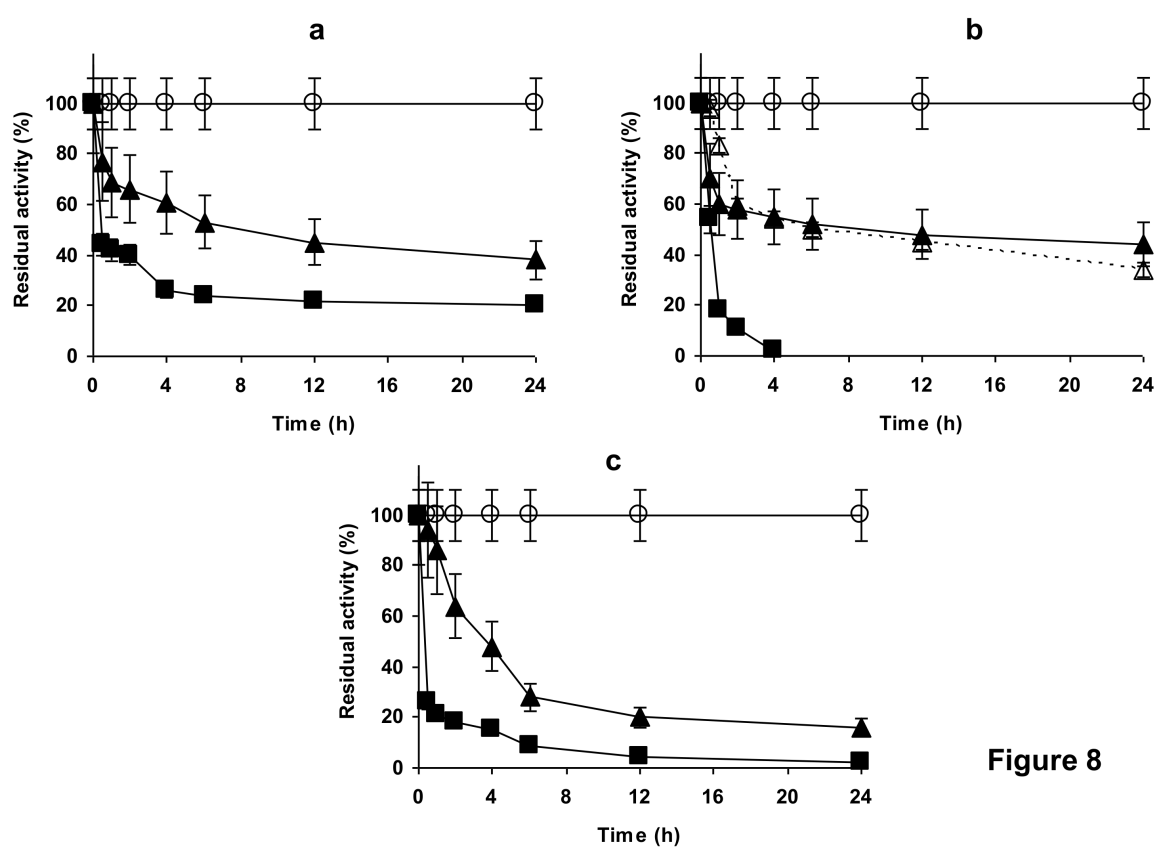

Figure 8

Figure 8. Immobilization of ficin extract on MANAE-agarose beads activated with glutaraldehyde. Experiments were performed as described in the Section 3 using $25 \mathrm{mM}$ of buffer, at pH 5 (a), 7 (b) or 9 (c). Open circles, solid lines: reference; Using BANA as substrate (solid lines, solid symbols): Triangles: suspension, Squares: supernatant. Using casein as substrate (only at $\mathrm{pH}$ 7): dotted line, empty triangles. 
Many reports stated that covalent glutaraldehyde immobilization is so slow that, if ion exchange was permitted, immobilization proceeded via a first ion exchange, followed by the covalent reaction. Figure 9 shows the immobilization of ficin extract at pH 7 and $200 \mathrm{mM}$ sodium phosphate, where ion exchange was prevented. The immobilization course is pretty similar to the use of $25 \mathrm{mM}$, suggesting that in both cases the immobilization mainly proceeded via a first covalent attachment. After $4 \mathrm{~h}$, the enzyme could not be desorbed from the support by incubating the biocatalysts in $500 \mathrm{mM} \mathrm{NaCl}$. We analysed the results obtained when immobilizing at $\mathrm{pH}$ from 6.5 to 8.5 and the results in terms of activity and stability were optimal at $\mathrm{pH} 7-8$, with a slight advantage at $\mathrm{pH} 7$ (results not shown). Thus, $\mathrm{pH} 7$ was selected as optimal $\mathrm{pH}$ for the enzyme immobilization on this support.

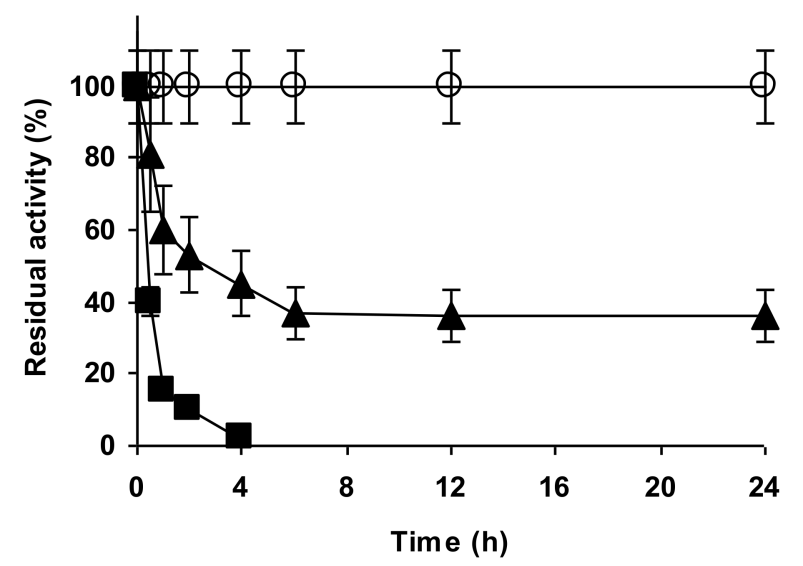

Figure 9. Immobilization of ficin extract on MANAE-agarose beads activated with glutaraldehyde at $\mathrm{pH} 7$ and $200 \mathrm{mM}$ sodium phosphate using BANA as substrate. Experiments were performed as described in Methods, using BANA as substrate. Circles: reference; Triangles: suspension, Squares: supernatant.

\subsection{Stability of the Enzyme Immobilized at $\mathrm{pH} 7$ on Glutaraldehyde Pre-Activated MANAE Agarose Beads}

The enzyme immobilized at $\mathrm{pH} 7$ at low and high ionic strength presented a very similar behaviour, thus we have just shown the results obtained with the enzyme immobilized at $25 \mathrm{mM}$ sodium phosphate. Figure 10 shows the inactivation courses at $\mathrm{pH} \mathrm{5,7}$ and 9, of the free and immobilized enzymes, followed with BANA and casein hydrolyses. Results suggested that a certain stabilization has been achieved using this support but stabilization was clearer at $\mathrm{pH} 7$ than at $\mathrm{pH} 5$ or 9. These differences in stabilization may be due to different interactions of the enzyme and the support-as the support remained as an ion exchanger-or to the fact the enzyme may follow different pathways in the inactivations, that way the immobilization by a specific area may affect enzyme stability in different ways [53]. Using BANA, the immobilized enzyme always seemed to be slightly more stable than when using casein, suggesting that the activity versus the casein is lost before the activity versus BANA. This was more evident at $\mathrm{pH} 7$ than at the other $\mathrm{pH}$ values. The situation was not so evident using the free enzyme, where inactivations were very similar with both substrates at pH 5, while at pH 7 and 9 higher stability using casein as substrate was observed. In fact, stabilization at $\mathrm{pH} 5$ and 7 caused by the enzyme immobilization was smaller using casein as substrate than using BANA. This finding may be related to different changes on the enzyme structure that may affect more significantly to the hydrolysis of one substrate or other one. 
a
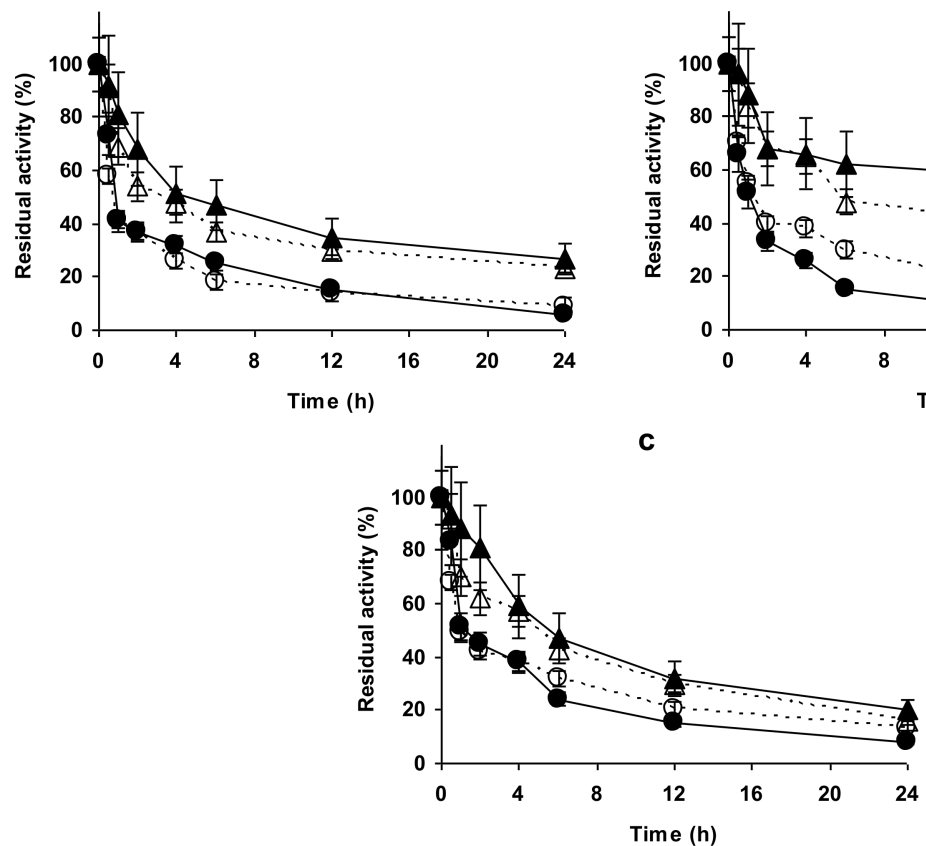

b

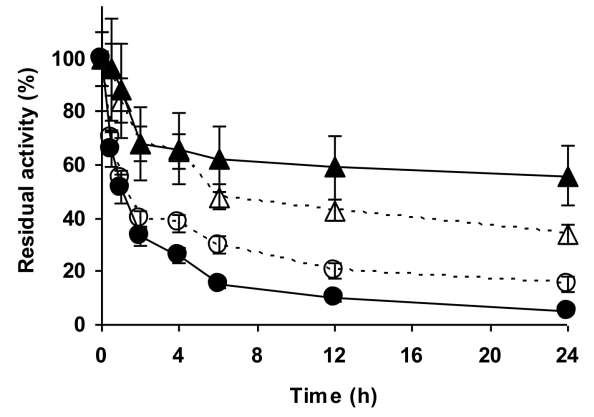

Figure 10

Figure 10. Inactivation of ficin immobilized at $\mathrm{pH} 7 \mathrm{using} 25 \mathrm{mM}$ sodium phosphate. Experiments were performed as described in Section 3, at pH 5 (a), 7 (b) or 9 (c) and $55^{\circ} \mathrm{C}$. Solid lines and solid circles: inactivation was followed using BANA, Dotted line and empty symbols: inactivation was followed with casein. Circles: free enzyme; Triangles: immobilized enzyme.

\subsection{Determination of Loading Capacity}

Figure 11 shows the immobilization yields when the amount of enzyme was increased using BANA and casein. From these experiments, maximum loading was established in the range 68-72 mg ficin/g of support. Expressed activity per mg of enzyme versus the small synthetic substrate was slightly lower when using higher enzyme loadings, although the values were pretty similar. The small differences may be attributed to an increment of the diffusion limitations.

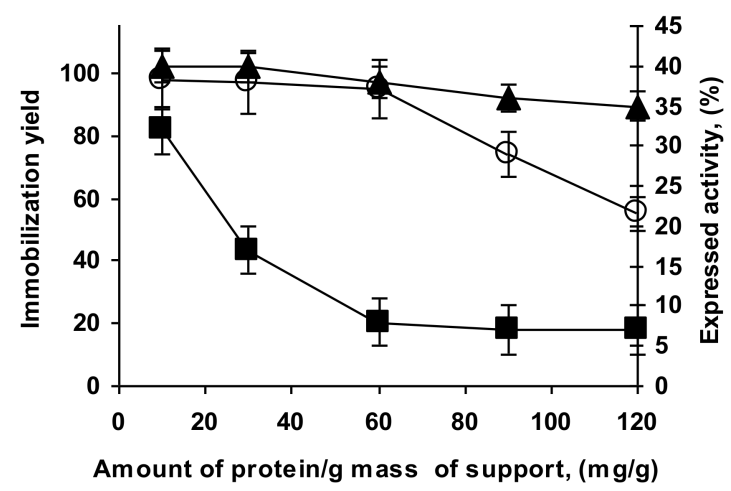

Figure 11. Immobilization yield and expressed activity when growing the amount of offered ficin extract per $g$ of MANAE activate with glutaraldehyde support. Experiments were carried out as described in Methods section. Triangles: immobilization yield; Circles: expressed activity versus BANA, Squares: expressed activity versus casein.

One critical point using proteases to hydrolyse proteins, as stated in the introduction, is that the loading of the support with the enzyme may generate some steric hindrances that prevent the accessibility of the large substrate to the enzyme if the orientation is not perfect towards the reaction medium [1]. Figure 11 shows that using casein the specific activity of the immobilized ficin 
extract rapidly decreased with increasing loading, going from slightly more than $30 \%$ of the activity immobilized at $10 \mathrm{mg} / \mathrm{g}$ to around $15 \%$ using $30 \mathrm{mg} / \mathrm{g}$ and only $7-8 \%$ using maximum loading or overloading. In fact, the observed activity per gram of biocatalyst was maximal using $30 \mathrm{mg} / \mathrm{g}$, using higher enzyme loading the biocatalyst mass activity decreased by $30-35 \%$. This suggested that the enzyme active centre was not perfectly looking toward the opposite side of the support surface and that way the nearby enzyme molecules may cause steric hindrances to the entry of the large substrate casein when the support was fully loaded. However, this limitation only affected the use of the biocatalyst in the hydrolysis of proteins, not in the other applications that the enzyme may have and that involve small substrates (see Section 1).

Another point that may have interest was to determine if the loading may somehow affect the immobilized ficin enzyme molecule stability. If the immobilization rate is high enough, it is likely that some molecules may be packed together and near enough to interact with each other, altering the final stability properties in a positive or a negative way, depending on the enzyme and inactivation conditions $[48,49]$. However, when we analysed this effect, we did not find any significant difference among the different preparations, just a very slight higher stability of the more loaded preparations; differences are scarce and may be attributed to diffusional limitations (e.g., after $6 \mathrm{~h}$, the biocatalyst having $1 \mathrm{mg} / \mathrm{g}$ retained a $55 \pm 2 \%$ of the initial activity, while the one prepared using $12 \mathrm{mg}$ retained $60 \pm 2 \%)$.

Using the preparation with $1 \mathrm{mg} / \mathrm{g}$ in hydrolysis of casein, we have reused the biocatalyst in 6 consecutive cycles of casein hydrolysis at $50^{\circ} \mathrm{C}$ and $\mathrm{pH} 7$ for $2 \mathrm{~h}$ without detecting any significant change in the biocatalyst performance (not shown results).

\section{Materials and Methods}

\subsection{Materials}

Glycidol, 25\% $(v / v)$ glutaraldehyde solution, sodium borohydride, sodium periodate, ethylenediamine, benzoyl-arginine-p-nitroanilide (BANA), cysteine, bovine serum albumin (BSA) and casein were purchased from Sigma-Aldrich (St. Louis, MO, USA). Agarose beads 4 BCL support was purchased from Agarose Bead Technologies (ABT), Madrid, Spain. All other reagents were of analytical grade. All experiments were performed by triplicate and the reported values the mean of the results of this set of experiments with their standard deviation. Glyoxyl agarose beads were prepared as previously described [54,55]. MANAE- supports was prepared from glyoxyl supports with a modification of the protocol previously described [56,57], ethylenediamine/glyoxyl agarose beads reaction time was $24 \mathrm{~h}$ before reduction. Glyoxyl-ficin was prepared using $1 \mathrm{mg}$ ficin/g of support as previously described [40].

\subsection{Preparation of Glutaraldehyde Agarose Beads}

50 grams of MANAE agarose beads was suspended in $100 \mathrm{~mL}$ of $15 \%(v / v)$ glutaraldehyde in $200 \mathrm{mM}$ phosphate buffer $\mathrm{pH}$ 7.0. The suspension was gently stirred $14-16 \mathrm{~h}$ at $4{ }^{\circ} \mathrm{C}$. After that, the activated support was washed with distilled water. The activated support was used immediately after preparation. This protocol guarantees that each primary amino in the support has been modified with two glutaraldehyde molecules [44,58,59].

\subsection{Preparation of Ficin Extract}

Fresh fig latex was obtained breaking fresh immature green fruits and leaves of Ficus carica L. The samples were picked in Kabylia, north of Algeria (Adekar, Bejaia). The fluid was collected in a clean flask at $4{ }^{\circ} \mathrm{C}$. The latex was centrifuged at $3200 \times \mathrm{g}$ for $15 \mathrm{~min}$ at $4{ }^{\circ} \mathrm{C}$ [60] to eliminate debris (e.g., gums). The supernatant was used as "crude extract of ficin" (with a concentration of $98.5 \mathrm{mg}$ protein $/ \mathrm{mL}$ ). The extract contains the four protease isoforms and it is similar to the usually utilized in ficin applications. A SDS-PAGE may be observed in support ting information. It was stored at $-20^{\circ} \mathrm{C}$ 
until use. The protein concentration was quantified by Bradford's method [61]. BSA was used as the standard protein. The activity of the free enzyme versus casein (see below) was $5 \pm 0.7$ units $/ \mathrm{mg}$ of protein.

\subsection{Enzymatic Assays}

Activity of immobilized and free ficin extract was determined using casein and benzoyl-D, L-arginine $p$-nitroanilide hydrochloride (BANA) as enzyme substrates.

The enzyme activity determination using BANA was performed as previously described [29], BANA solution was prepared by dissolving $43.5 \mathrm{mg}$ of BANA in $1.0 \mathrm{~mL}$ of dimethyl sulfoxide and diluting to $100 \mathrm{~mL}$ in $0.1 \mathrm{M}$ sodium phosphate $\mathrm{pH} 7$, containing $5 \mathrm{mM}$ EDTA. The enzyme activity was assessed by measuring the $p$-nitroaniline released at $405 \mathrm{~nm}$ (under these conditions, the $\varepsilon$ for $p$-nitroaniline was 8800). Activity of ficin was expressed as $\mu$ mols of $p$-nitroaniline released per $\mathrm{mg}$ of extract and min.

The enzyme activity using casein was determined as described by Kunitz, with some modifications [62]. A solution of $1 \%(w / v)$ casein was prepared in $100 \mathrm{mM}$ sodium phosphate at $\mathrm{pH} 7.0$ containing $5 \mathrm{mM}$ cysteine hydrochloride and $5 \mathrm{mM}$ EDTA at $55^{\circ} \mathrm{C}$. To $1 \mathrm{~mL}$ of this substrate solution, $100 \mu \mathrm{L}$ of ficin (enzyme extract solution or immobilized ficin suspension) was added and the reaction mixture was incubated at the desired temperature for $20 \mathrm{~min}$. The reaction was stopped by the addition of $1 \mathrm{~mL}$ of $10 \%$ trichloroacetic acid (TCA), incubated for $10 \mathrm{~min}$ at room temperature and centrifuged at 10,000 rpm. This treatment produces the precipitation of the remaining protein but the peptides remained in solution. The absorbance of soluble peptides in the supernatant was measured at $280 \mathrm{~nm}$. In the case of the reference, substrate was added after the enzyme was first inactivated by incubation in TCA. One unit of activity is defined as increment in absorbance of 0.001 per $\mathrm{mg}$ of ficin and min under the given assay conditions.

\subsection{Immobilization of Ficin Extract}

Ten grams (10 g) of the corresponding support (MANAE-agarose or glutaraldehyde-agarose) were added to $100 \mathrm{~mL}$ of ficin extract (containing $1 \mathrm{mg}$ protein/mL) in $25 \mathrm{mM}$ sodium acetate at pH 5, $25 \mathrm{mM}$ sodium phosphate at $\mathrm{pH} 6.5-8.5$ or $25 \mathrm{mM}$ sodium carbonate at $\mathrm{pH} 9$, in all cases the temperature was $25^{\circ} \mathrm{C}$. In some instances, the enzyme concentration was increased to increase the amount of offered enzyme (a maximum of $12 \mathrm{mg} / \mathrm{mL}$ was employed). Samples from suspensions and supernatants were periodically withdrawn and their catalytic activity determined using BANA and casein. After $24 \mathrm{~h}$, the biocatalysts were vacuum filtered and washed thoroughly with distilled water.

\subsection{Enzyme Inactivation Studies}

$1 \mathrm{~g}$ of immobilized enzyme was suspended in $10 \mathrm{~mL}$ of $50 \mathrm{mM}$ in the corresponding buffer at $55^{\circ} \mathrm{C}$ (sodium acetate at $\mathrm{pH} 5$, sodium phosphate at $\mathrm{pH} 7$ or $50 \mathrm{mM}$ sodium carbonate at $\mathrm{pH} 9$ ). For the free enzyme extract, $1 \mathrm{mg} / \mathrm{mL}$ of ficin solution was prepared in the same buffer and temperature. Samples were periodically withdrawn and the activity determined using the BANA and casein assay described above.

\subsection{Reuse of the Immobilized Ficin in the Hydrolysis of Casein}

Six cycles of casein hydrolysis ( $2 \mathrm{~h}$ each) were performed at $50{ }^{\circ} \mathrm{C}$ and $\mathrm{pH}$. After $2 \mathrm{~h}$ of casein proteolysis, the peptide production was checked as described above and the immobilized enzyme was washed 5 times with 10 volumes of distilled water and employed in a new reaction cycle.

\section{Conclusions}

Ficin extract may be immobilized on glutaraldehyde activated supports, best results in terms of immobilization yield and expressed activity are achieved when the enzyme is immobilized at $\mathrm{pH} 7$. 
Immobilization at 25 or $200 \mathrm{mM}$ sodium phosphate is relatively similar, while the aminated support is unable to immobilize more than $30-40 \%$ of the enzyme. This suggested that the first immobilization step is in both cases the covalent attachment of the enzyme. Immobilization at $\mathrm{pH} 5$ failed in permitting full enzyme immobilization, while at $\mathrm{pH} 9$ the enzyme become inactivated. Stabilization depended on the $\mathrm{pH}$ and the substrate used to determine the residual activity, being larger when using BANA and shorter using casein. Results suggest a complex net of interactions between enzyme and support that differently affect the activity versus the different substrates. For the hydrolysis of casein, enzyme specific activity drops rapidly using high loadings, while it is almost identical using BANA. Enzyme loading has not a significant effect on immobilized enzyme stability.

Supplementary Materials: The following are available online at http:/ /www.mdpi.com/2073-4344/8/4/149/s1, Figure S1: SDS PAGE of ficin extract $(1 \mathrm{mg} / \mathrm{ml})$. Lane 1 Molecular weight markers, Lane 2, 3, 4 different ficin extracts used in this paper.

Acknowledgments: We gratefully recognize the support from the MINECO from Spanish Government, (project number CTQ2017-86170-R). El-Hocine Siar thanks the Algerian Ministry of Higher Education and Scientific Research for his fellowship. The help and suggestions of Ángel Berenguer (Instituto de Materiales, Universidad de Alicante) are gratefully recognized.

Author Contributions: R.F.-L. and M.N.Z. conceived the experiments; R.F.-L. designed and supervised the experiments, E.-H.A., S.A.-P. and O.B. performed the experiments, E.-H.A., S.A.-P. and R.F.-L. wrote the paper.

Conflicts of Interest: The authors declare no conflict of interest. The founding sponsors had no role in the design of the study; in the collection, analyses, or interpretation of data; in the writing of the manuscript and in the decision to publish the results.

\section{References}

1. Tavano, O.L.; Berenguer-Murcia, A.; Secundo, F.; Fernandez-Lafuente, R. Biotechnological Applications of Proteases in Food Technology. Compr. Rev. Food Sci. Food Saf. 2018, 17, 412-436. [CrossRef]

2. Tavano, O.L. Protein hydrolysis using proteases: An important tool for food biotechnology. J. Mol. Catal. B Enzym. 2013, 90, 1-11. [CrossRef]

3. Clemente, A. Enzymatic protein hydrolysates in human nutrition. Trends Food Sci. Technol. 2000, 11, 254-262. [CrossRef]

4. Maurer, K.H. Detergent proteases. Curr. Opin. Biotechnol. 2004, 15, 330-334. [CrossRef] [PubMed]

5. Banerjee, U.C.; Sani, R.K.; Azmi, W.; Soni, R. Thermostable alkaline protease from Bacillus brevis and its characterization as a laundry detergent additive. Process Biochem. 1999, 35, 213-219. [CrossRef]

6. Phadatare, S.U.; Deshpande, V.V.; Srinivasan, M.C. High activity alkaline protease from Conidiobolus coronatus (NCL 86.8.20): Enzyme production and compatibility with commercial detergents. Enzyme Microb. Technol. 1993, 15, 72-76. [CrossRef]

7. David, A.; Singh, C.P.; Kumar, A.; Angural, S.; Kumar, D.; Puri, N.; Gupta, N. Coproduction of protease and mannanase from Bacillus nealsonii PN-11 in solid state fermentation and their combined application as detergent additives. Int. J. Biol. Macromol. 2018, 108, 1176-1184. [CrossRef] [PubMed]

8. Cuq, J.C.; Vi, M.; Cheftel, J.C. Tryptophan degradation during heat treatments: Part 2-Degradation of protein-bound tryptophan. Food Chem. 1983, 12, 73-88. [CrossRef]

9. Masuda, A.; Dohmae, N. Automated protein hydrolysis delivering sample to a solid acid catalyst for amino acid analysis. Anal. Chem. 2010, 82, 8939-8945. [CrossRef] [PubMed]

10. Feijoo-Siota, L.; Villa, T.G. Native and Biotechnologically Engineered Plant Proteases with Industrial Applications. Food Bioprocess Technol. 2011, 4, 1066-1088. [CrossRef]

11. Shah, M.A.; Mir, S.A.; Paray, M.A. Plant proteases as milk-clotting enzymes in cheesemaking: A review. Dairy Sci. Technol. 2014, 94, 5-16. [CrossRef]

12. Faccia, M.; Picariello, G.; Trani, A.; Loizzo, P.; Gambacorta, G.; Lamacchia, C.; Di Luccia, A. Proteolysis of Cacioricotta cheese made from goat milk coagulated with caprifig (Ficus carica sylvestris) or calf rennet. Eur. Food Res. Technol. 2012, 234, 527-533. [CrossRef]

13. Esmaeilpour, M.; Ehsani, M.R.; Aminlari, M.; Shekarforoush, S.; Hoseini, E. Antimicrobial activity of peptides derived from enzymatic hydrolysis of goat milk caseins. Comp. Clin. Pathol. 2016, 25, 599-605. [CrossRef] 
14. Di Pierro, G.; O’Keeffe, M.B.; Poyarkov, A.; Lomolino, G.; Fitzgerald, R.J. Antioxidant activity of bovine casein hydrolysates produced by Ficus carica L.-derived proteinase. Food Chem. 2014, 156, 305-311. [CrossRef] [PubMed]

15. Bekhit, A.A.; Hopkins, D.L.; Geesink, G.; Bekhit, A.A.; Franks, P. Exogenous Proteases for Meat Tenderization. Crit. Rev. Food Sci. Nutr. 2014, 54, 1012-1031. [CrossRef] [PubMed]

16. Sullivan, G.A.; Calkins, C.R. Application of exogenous enzymes to beef muscle of high and low-connective tissue. Meat Sci. 2010, 85, 730-734. [CrossRef] [PubMed]

17. Mariant, M.; Camagna, M.; Tarditi, L.; Seccamani, E. A new enzymatic method to obtain high-yield F(ab)2 suitable for clinical use from mouse IgGl. Mol. Immunol. 1991, 28, 69-77. [CrossRef]

18. Sham, J.G.; Kievit, F.M.; Grierson, J.R.; Chiarelli, P.A.; Miyaoka, R.S.; Zhang, M.; Yeung, R.S.; Minoshima, S.; Park, J.O. Glypican-3-targeting F(ab')2 for 89Zr PET of hepatocellular carcinoma. J. Nucl. Med. 2014, 55, 2032-2037. [CrossRef] [PubMed]

19. Saczyńska, V.; Bierczyńska-Krzysik, A.; Cecuda-Adamczewska, V.; Baran, P.; Porębska, A.; Florys, K.; Zieliński, M.; Płucienniczak, G. Production of highly and broad-range specific monoclonal antibodies against hemagglutinin of H5-subtype avian influenza viruses and their differentiation by mass spectrometry. Virol. J. 2018, 15, 13. [CrossRef] [PubMed]

20. Haesaerts, S.; Rodriguez Buitrago, J.A.; Loris, R.; Baeyens-Volant, D.; Azarkan, M. Crystallization and preliminary X-ray analysis of four cysteine proteases from Ficus carica latex. Acta Crystallogr. Sect. F Struct. Biol. Cryst. Commun. 2015, 71, 459-465. [CrossRef] [PubMed]

21. Zare, H.; Moosavi-Movahedi, A.A.; Salami, M.; Mirzaei, M.; Saboury, A.A.; Sheibani, N. Purification and autolysis of the ficin isoforms from fig (Ficus carica cv. Sabz) latex. Phytochemistry 2013, 87, 16-22. [CrossRef] [PubMed]

22. Devaraj, K.B.; Kumar, P.R.; Prakash, V. Purification, characterization, and solvent-induced thermal stabilization of ficin from Ficus carica. J. Agric. Food Chem. 2008, 56, 11417-11423. [CrossRef] [PubMed]

23. Di Cosimo, R.; McAuliffe, J.; Poulose, A.J.; Bohlmann, G. Industrial use of immobilized enzymes. Chem. Soc. Rev. 2013, 42, 6437-6474. [CrossRef]

24. Cantone, S.; Ferrario, V.; Corici, L.; Ebert, C.; Fattor, D.; Spizzo, P.; Gardossi, L. Efficient immobilisation of industrial biocatalysts: Criteria and constraints for the selection of organic polymeric carriers and immobilisation methods. Chem. Soc. Rev. 2013, 42, 6262-6276. [CrossRef] [PubMed]

25. Sheldon, R.A.; van Pelt, S. Enzyme immobilisation in biocatalysis: Why, what and how. Chem. Soc. Rev. 2013, 42, 6223-6235. [CrossRef] [PubMed]

26. Liese, A.; Hilterhaus, L. Evaluation of immobilized enzymes for industrial applications. Chem. Soc. Rev. 2013, 42, 6236-6249. [CrossRef] [PubMed]

27. Mateo, C.; Palomo, J.M.; Fernandez-Lorente, G.; Guisan, J.M.; Fernandez-Lafuente, R. Improvement of enzyme activity, stability and selectivity via immobilization techniques. Enzyme Microb. Technol. 2007, 40, 1451-1463. [CrossRef]

28. Barbosa, O.; Ortiz, C.; Berenguer-Murcia, Á.; Torres, R.; Rodrigues, R.C.; Fernandez-Lafuente, R. Strategies for the one-step immobilization-purification of enzymes as industrial biocatalysts. Biotechnol. Adv. 2015, 33, 435-456. [CrossRef] [PubMed]

29. Santos, J.C.S.D.; Barbosa, O.; Ortiz, C.; Berenguer-Murcia, A.; Rodrigues, R.C.; Fernandez-Lafuente, R. Importance of the Support Properties for Immobilization or Purification of Enzymes. ChemCatChem 2015, 7, 2413-2432. [CrossRef]

30. Garcia-Galan, C.; Berenguer-Murcia, A.; Fernandez-Lafuente, R.; Rodrigues, R.C. Potential of different enzyme immobilization strategies to improve enzyme performance. Adv. Synth. Catal. 2011, 35, 2885-2904. [CrossRef]

31. Rodrigues, R.C.; Ortiz, C.; Berenguer-Murcia, A.; Torres, R.; Fernández-Lafuente, R. Modifying enzyme activity and selectivity by immobilization. Chem. Soc. Rev. 2013, 42, 6290-6307. [CrossRef] [PubMed]

32. Cipolatti, E.P.; Valério, A.; Henriques, R.O.; Moritz, D.E.; Ninow, J.L.; Freire, D.M.G.; Manoel, E.A.; Fernandez-Lafuente, R.; De Oliveira, D. Nanomaterials for biocatalyst immobilization-state of the art and future trends. RSC Adv. 2016, 6, 104675-104692. [CrossRef]

33. Wang, M.; Qi, W.; Yu, Q.; Su, R.; He, Z. Kinetically controlled enzymatic synthesis of dipeptide precursor of L-alanyl-L-glutamine. Biotechnol. Appl. Biochem. 2011, 58, 449-455. [CrossRef] [PubMed] 
34. Kumar, D.; Bhalla, T.C. Microbial proteases in peptide synthesis: Approaches and applications. Appl. Microbiol. Biotechnol. 2015, 68, 726-736. [CrossRef] [PubMed]

35. Lombard, C.; Saulnier, J.; Wallach, J.M. Recent trends in protease-catalyzed peptide synthesis. Protein Pept. Lett. 2005, 12, 621-629. [CrossRef] [PubMed]

36. Hayashi, T.; Ikada, Y. Protease immobilization onto porous chitosan beads. J. Appl. Polym. Sci. 1991, 42, 85-92. [CrossRef]

37. Hayashi, T.; Hyon, S.-H.; Cha, W.; Ikada, Y. Immobilization of thiol proteases onto porous poly(vinyl alcohol) beads. Polym. J. 1993, 25, 489-497. [CrossRef]

38. Tai, D.F.; Huang, H.Y.; Huang, C.C. Immobilized ficin catalyzed synthesis of peptides in organic solvent. Bioorg. Med. Chem. Lett. 1995, 5, 1475-1478. [CrossRef]

39. Jasim, M.A.; Hall, G.M.; Mann, J.; Taylor, K.D.A. A comparison of immobilised protease activities. J. Chem. Technol. Biotechnol. 1987, 40, 251-258. [CrossRef]

40. Siar, E.-H.; Zaak, H.; Kornecki, J.F.; Zidoune, M.N.; Barbosa, O.; Fernandez-Lafuente, R. Stabilization of ficin extract by immobilization on glyoxyl agarose. Preliminary characterization of the biocatalyst performance in hydrolysis of proteins. Process Biochem. 2017, 58, 98-104. [CrossRef]

41. Barbosa, O.; Ortiz, C.; Berenguer-Murcia, A.; Torres, R.; Rodrigues, R.C.; Fernandez-Lafuente, R. Glutaraldehyde in bio-catalysts design: A useful crosslinker and a versatile tool in enzyme immobilization. RSC Adv. 2014, 4, 1583-1600. [CrossRef]

42. Betancor, L.; López-Gallego, F.; Hidalgo, A.; Alonso-Morales, N.; Dellamora-Ortiz, G.; Mateo, C.; Fernández-Lafuente, R.; Guisán, J.M. Different mechanisms of protein immobilization on glutaraldehyde activated supports: Effect of support activation and immobilization conditions. Enzyme Microb. Technol. 2006, 39, 877-882. [CrossRef]

43. López-Gallego, F.; Betancor, L.; Mateo, C.; Hidalgo, A.; Alonso-Morales, N.; Dellamora-Ortiz, G.; Guisán, J.M.; Fernández-Lafuente, R. Enzyme stabilization by glutaraldehyde crosslinking of adsorbed proteins on aminated supports. J. Biotechnol. 2005, 119, 70-75. [CrossRef] [PubMed]

44. Barbosa, O.; Torres, R.; Ortiz, C.; Fernandez-Lafuente, R. Versatility of glutaraldehyde to immobilize lipases: Effect of the immobilization protocol on the properties of lipase B from Candida antárctica. Process Biochem. 2012, 47, 1220-1227. [CrossRef]

45. Zaak, H.; Peirce, S.; de Albuquerque, T.L.; Sassi, M.; Fernandez-Lafuente, R. Exploiting the versatility of aminated supports activated with glutaraldehyde to immobilize $\beta$-galactosidase from Aspergillus oryzae. Catalysts 2017, 7, 250. [CrossRef]

46. Vazquez-Ortega, P.G.; Alcaraz-Fructuoso, M.T.; Rojas-Contreras, J.A.; López-Miranda, J.; Fernandez-Lafuente, R. Stabilization of dimeric $\beta$-glucosidase from Aspergillus niger via glutaraldehyde immobilization under different conditions. Enzyme Microb. Technol. 2018, 110, 38-45. [CrossRef] [PubMed]

47. De Albuquerque, T.L.; Peirce, S.; Rueda, N.; Marzocchella, A.; Gonçalves, L.R.B.; Rocha, M.V.P.; Fernandez-Lafuente, R. Ion exchange of $\beta$-galactosidase: The effect of the immobilization $\mathrm{pH}$ on enzyme stability. Process Biochem. 2016, 51, 875-880. [CrossRef]

48. Fernandez-Lopez, L.; Pedrero, S.G.; Lopez-Carrobles, N.; Gorines, B.C.; Virgen-Ortíz, J.J.; Fernandez-Lafuente, R. Effect of protein load on stability of immobilized enzymes. Enzyme Microb. Technol. 2017, 98, 18-25. [CrossRef] [PubMed]

49. Zaak, H.; Siar, E.H.; Kornecki, J.F.; Fernandez-Lopez, L.; Pedrero, S.G.; Virgen-Ortíz, J.J.; Fernandez-Lafuente, R. Effect of immobilization rate and enzyme crowding on enzyme stability under different conditions. The case of lipase from Thermomyces lanuginosus immobilized on octyl agarose beads. Process Biochem. 2017, 56, 117-123. [CrossRef]

50. Virgen-Ortíz, J.J.; Pedrero, S.G.; Fernandez-Lopez, L.; Lopez-Carrobles, N.; Gorines, B.C.; Otero, C.; Fernandez-Lafuente, R. Desorption of lipases immobilized on octyl-agarose beads and coated with ionic polymers after thermal inactivation. Stronger adsorption of polymers/unfolded protein composites. Molecules 2017, 22, 91. [CrossRef]

51. Virgen-Ortíz, J.J.; Peirce, S.; Tacias-Pascacio, V.G.; Cortes-Corberan, V.; Marzocchella, A.; Russo, M.E.; Fernandez-Lafuente, R. Reuse of anion exchangers as supports for enzyme immobilization: Reinforcement of the enzyme-support multiinteraction after enzyme inactivation. Process Biochem. 2016, 51, 1391-1396. [CrossRef] 
52. Fernandez-Lafuente, R.; Rosell, C.M.; Rodriguez, V.; Guisan, J.M. Strategies for enzyme stabilization by intramolecular crosslinking with bifunctional reagents. Enzyme Microb. Technol. 1995, 17, 517-523. [CrossRef]

53. Sanchez, A.; Cruz, J.; Rueda, N.; Dos Santos, J.C.S.; Torres, R.; Ortiz, C.; Villalonga, R.; Fernandez-Lafuente, R. Inactivation of immobilized trypsin under dissimilar conditions produces trypsin molecules with different structures. RSC Adv. 2016, 6, 27329-27334. [CrossRef]

54. Mateo, C.; Abian, O.; Bernedo, M.; Cuenca, E.; Fuentes, M.; Fernandez-Lorente, G.; Palomo, J.M.; Grazu, V.; Pessela, B.C.C.; Giacomini, C.; et al. Some special features of glyoxyl supports to immobilize proteins. Enzyme Microb. Technol. 2005, 37, 456-462. [CrossRef]

55. Grazu, V.; Betancor, L.; Montes, T.; Lopez-Gallego, F.; Guisan, J.M.; Fernandez-Lafuente, R. Glyoxyl agarose as a new chromatographic matrix. Enzyme Microb. Technol. 2006, 38, 960-966. [CrossRef]

56. Mateo, C.; Palomo, J.M.; Fuentes, M.; Betancor, L.; Grazú, V.; Lopez-Gallego, F.; Pessela, B.C.C.; Hidalgo, A.; Fernández-Lorente, G.; Fernández-Lafuente, R. Glyoxyl agarose: A fully inert and hydrophilic support for immobilization and high stabilization of proteins. Enzyme Microb. Technol. 2006, 39, 274-280. [CrossRef]

57. Fernández-Lafuente, R.; Rosell, C.M.; Rodriguez, V.; Santana, C.; Soler, G.; Bastida, A.; Guisán, J.M. Preparation of activated supports containing low $\mathrm{pK}$ amino groups. A new tool for protein immobilization via the carboxyl coupling method. Enzyme Microb. Technol. 1993, 15, 546-550. [CrossRef]

58. Corma, A.; Fornés, V.; Jordá, J.L.; Rey, F.; Fernandez-Lafuente, R.; Guisan, J.M.; Mateo, C. Electrostatic and covalent immobilisation of enzymes on ITQ-6 delaminated zeolitic materials. Chem. Commun. 2001, 5, 419-420. [CrossRef]

59. Betancor, L.; López-Gallego, F.; Alonso-Morales, N.; Dellamora, G.; Mateo, C.; Fernandez-Lafuente, R.; Guisan, J.M. Glutaraldehyde in Protein Immobilization. A Versatile Reagent. In Immobilization of Enzymes and Cells, 2nd ed.; Guisan, J.M., Ed.; Humana Press Inc.: New York, NY, USA, 2006; pp. 57-64, ISBN 1-58829-290-8.

60. Nouani, A.; Dako, E.; Morsli, A.; Belhamiche, N.; Belbraouet, S.; Bellal, M.M.; Dadie, A. Characterization of the purified coagulant extracts derived from artichoke flowers (Cynaras scolymus) and from the fig tree latex (Ficus carica) in light of their use in the manufacture of traditional cheeses in Algeria. J. Food Technol. 2009, 7, 20-29.

61. Bradford, M.M. A rapid and sensitive method for the quantitation of microgram quantities of protein utilizing the principle of protein-dye binding. Anal. Biochem. 1976, 72, 248-254. [CrossRef]

62. Kunitz, M.J. Crystalline soybean trypsin inhibitor: II. General properties. J. Gen. Physiol. 1947, 30, $291-310$. [CrossRef] [PubMed] 